\title{
Does facility type and location impact upon patient experiences in emergency \\ departments? Secondary analysis of a state-wide, cross-sectional survey
}

${ }^{1}$ Claudia Bull, BNutr(Hons), $\mathrm{PhD}$ Candidate

1,2 Julia Crilly, RN, BN, MEmergN(Hons), PhD, Professor

${ }^{1}$ Wendy Chaboyer, RN, BSc, PhD, Professor and Deputy Head of School

${ }^{2}$ David Spain, MBBS, FRACGP, FACEM, Deputy Medical Director Emergency Department

${ }^{3}$ Brendan Mulhern, BSc, MRes, Senior Research Fellow

${ }^{4}$ Gerard FitzGerald, MD, FACEM, FRACMA, Professor Emeritus

${ }^{5}$ Paul Scuffham, BA, PhD, FAHMS, Director Menzies Health Institute Queensland (MHIQ)

${ }^{5}$ Joshua Byrnes, BEcon BComm Mecon MHlthEcon, PhD, Associate Professor

${ }^{1}$ School of Nursing and Midwifery, Menzies Health Institute Queensland (MHIQ), Griffith

University, Brisbane, Queensland, Australia

${ }^{2}$ Department of Emergency Medicine, Gold Coast Hospital and Health Service, Gold Coast, Queensland, Australia

${ }^{3}$ Centre for Health Economics Research and Evaluation (CHERE), University of Technology Sydney, Sydney, Australia

${ }^{4}$ Public Health and Health Services, Queensland University of Technology, Brisbane, Australia

${ }^{5}$ Centre for Applied Health Economics (CAHE), Menzies Health Institute Queensland (MHIQ), Griffith University, Brisbane, Queensland, Australia 
Correspondence: Claudia Bull, School of Nursing and Midwifery, Griffith University, Gold Coast Campus, 1 Parklands Drive, Southport, QLD, 4215, Australia. Email:

claudia.bull@griffithuni.edu.au. Telephone: (+610) 439791446.

Acknowledgements: This study was supported by an Emergency Medicine Foundation grant. CB is funded by an Australian Government Research Training Program (RTP) scholarship and a Griffith University Health Group top-up scholarship. We also thank the Health Innovation, Investment and Research Office of Queensland Health for supplying the data used in this study. No authors have competing interests to declare. 


\begin{abstract}
Objective: To identify the extent to which patient experiences in the Emergency Department (ED) differ depending on facility type (based on bed numbers, services available and annual separations), and location (level of remoteness).
\end{abstract}

Methods: Data from a 2015 state-wide (Queensland, Australia) public ED patient experience survey were linked to sociodemographic and presentation-related characteristics data. Survey items were individually scored (from 0-100), and averaged across 13 pre-determined patient experience topic areas. Descriptive statistics were used to report on patient sociodemographic and presentation-related characteristics. One-way analysis of variance tests were used to identify associations between patient-reported experience scores, facility types and location.

Results: A total of 10,553 patients over the age of 16-years completed the survey. All patients reported scores above 75 for 7 of the 13 patient experience topic areas $(0=$ lowest score, 100 $=$ highest score). Patients from very remote and outer regional EDs reported the highest scores for the topic Environment and facilities, and remote facility patients reported the highest score for the topic Leaving the ED - Delays. The same two topic areas were scored most highly by patients from smaller facilities in comparison to principal referral hospital EDs.

Conclusions: Patients attending smaller and more rurally located EDs reported more positive experiences than those attending larger, metropolitan EDs on two of the 13 topic areas. However, these differences were marginal. Future research should aim to determine what constitutes clinically meaningful differences between groups when comparing patientreported experience scores, and understand the characteristics of small and rural EDs that may be associated with better patient experiences. 
Keywords: Surveys and Questionnaires; Patients; Emergency Service, Hospital; Delivery of Health Care; Quality of Health Care 


\section{Introduction}

Hospital Emergency Departments (EDs) provide acute care services to patients of all ages and condition types, and play a pivotal role in linking community and hospital healthcare services. They are arguably the most unpredictable and chaotic care environment in modernday healthcare systems. Internationally, the number of presentations made to EDs each year is growing ${ }^{1,2}$. In Australia specifically, the increase in ED presentations during 2017-18 (3.4\%) was more than double the annual rate of population growth $(1.6 \%)^{3,4}$. This growth in demand contributes to issues such as overcrowding and long wait times ${ }^{5}$, and challenges EDs striving to provide safe, high quality healthcare.

Optimising patient experiences in healthcare is recognised as integral to the provision of high quality healthcare ${ }^{6-8}$ and the enactment of value-based healthcare ${ }^{9}$. Given the complexity of the care environment, and the distressed state in which many patients present, it is unsurprising that optimising patient experiences in the ED is a priority for many health service managers and organisational leaders globally ${ }^{10-12}$. To date, strong determinants of patient experiences in the ED include waiting times, the patient-provider relationship and the physical environment ${ }^{10,13}$. Yet, a paucity of research exists regarding the effects of facility type and location on patient experiences in the ED, despite evidence in the inpatient setting suggesting that facility characteristics such as bed numbers, teaching status and geographical location can influence patient-reported experiences ${ }^{14-18}$.

This study aimed to identify the extent to which patient experiences in the ED differ depending on facility type (based on the number of beds, services available and number of separations annually), and location (level of remoteness). This information may inform discussions related to how equivalent care experiences can be delivered within a universal 
healthcare system, irrespective of differences in the geographical location and size of facilities delivering care.

\section{Methods}

This study reports a secondary analysis of the 2015 Emergency Department Patient Experience Survey (EDPES) data collected during the $1^{\text {st }}$ of August $-30^{\text {th }}$ of September, 2015 from 51 public hospital EDs across Queensland (QLD), Australia. EDPES data were linked independently by statisticians at the Queensland Government Statistician's Office (QGSO), to respondent Emergency Department Information System (EDIS) records; the information system in use across QLD EDs at the time of the survey. This linked respondent EDPES scores with their individual sociodemographic and presentation-related data.

Administrative and sociodemographic data for individual patients over the age of 16 concurrently presenting to the same 51 EDs during the same time period were also collected. Data were unidentifiable and obtained through EDIS records.

Emergency Department Patient Experience Survey (EDPES) sample

A total of 10,553 individuals over the age of 16 were surveyed during the two-month period using computer-assisted technology interviewing (CATI $)^{19}$. Participants were randomly selected from their facility's EDIS records. A target sample size was calculated for each facility; where facilities were predicted not to meet the target sample size (or were very close to it), census sampling was undertaken ${ }^{19}$. Participant eligibility criteria is documented in Appendix 1.

Survey instrument

The 2015 EDPES is a 63-item patient-reported experience measure (PREM). It was developed from two previous versions of the same survey, which were in-turn developed 
from the UK's 2009 Care Quality Commission (CQC) Accident and Emergency (A\&E) Department Question Bank ${ }^{20}$. Items in the 2015 EDPES are grouped into 14 topic areas that reflect the sequence of events comprising a patient's experience in the ED (see Figure 1).

[Insert Figure 1 here]

Data analysis

Descriptive statistics were used to report on the sociodemographic and presentationrelated characteristics of the EDPES sample and concurrently presenting QLD ED population. Univariate logistic regression analysis was used to compare the representativeness of the EDPES sample to the concurrent population. EDPES items were individually scored on a linear scale ranging from $0-100$ following the process proposed in the QLD Health Emergency Department Patient Experience Survey 2015 report $^{19}$ (see Appendix 2). An overall topic area (TA) score was generated for each respondent based on an average of respondents' scores to all items comprising the pre-determined topic areas. Average EDPES topic area results were tabulated for the different facility types (6 categories), and facility locations (level of remoteness) (5 categories). EDs were coded into 'facility types' and 'location (level of remoteness)', according to the Australian Institute of Health and Welfare (AIHW) Australian hospital peer groups 2015 report $^{21}$ and the Australia Government Department of Health Australian Standard Geographical ClassificationRemoteness Area $(A S G C-R A)^{22}$, respectively. Table 1 outlines facility types based on services provided, bed numbers and number of hospital separations ${ }^{21}$.

[Insert Table 1 here]

The topic area Leaving the ED - Destination was comprised of a single item which was not scored ${ }^{19}$, leaving a total of 13 topic areas to be included in the analysis (topic area 14 is still referred to as 14). One-way analysis of variance (ANOVA) tests were used to identify 
whether mean topic area scores were significantly different between patients treated at different facility types and different locations (levels of remoteness). Due to the large sample size, statistical significance was set at $\alpha \leq 0.01$. The current study received ethical approval from the Gold Coast Hospital and Health Service and Griffith University Human Research Ethics Committees (LNR/2018/QGC/44522 and 2018/831, respectively). All data were analysed using StataSE13 (College Station, TX: StataCorp LP).

\section{Results}

A total of 10,553 patients over the age of 16 responded to the EDPES during the months of August and September, 2015. In comparison to the concurrently presenting QLD ED population $(n=219,503)$, the samples differed significantly $(p<0.001)$ in terms of age, mode of arrival to the ED, Australasian Triage Score (ATS) and episode end status (see Table 2). There were also significant differences $(p<0.001)$ between the numbers of patients presenting to EDs within the different facility types and remoteness levels.

[Insert Table 2 here]

Table 3 presents the average EDPES topic area scores for participants across the different facility types and locations (level of remoteness). Overall, participants reported the highest average scores for Environment and Facilities (TA8) (92.7 \pm 13.7$)$, indicating that patients viewed the ED environment and toilets as clean, they were able to access suitable food and drinks, and were not bothered or threatened by other patients or visitors (see Appendix 3 for items comprising TA8). This was followed closely by Care and Treatment (TA5) (90.2 \pm 15.2$)$, which was comprised of items related to whether patients felt respected, treated kindly, were involved in their care to the extent they wanted to be, and were given enough privacy (see Appendix 3 for items comprising TA5). 
Complaints (TA14) was scored lowest, on average, by all participants (28.2 \pm 45.0$)$. This topic area was based on one item (While you were in the ED, were you told or did you see a poster or brochure on how to [give feedback about the care your received]?), indicating that patients were unaware of how to provide feedback to ED services regarding the care they received. The second lowest scoring topic area was Leaving the EDcoordination of follow-up services (TA12) (62.2 \pm 44.2$)$, suggesting that patients did not feel as though adequate arrangements were made by the facility for follow-up services they may need. On average, participants reported scores of 75 or greater for 7 of the 13 topic areas.

With regards to the location (level of remoteness), little variation in the average topic area scores was evident, with no significant differences identified for 11 of the 13 topic areas (see Table 3). The two topic areas where a statistically significant difference was identified were: Environment and facilities (TA8) $(\mathrm{p}<0.01)$, with very remote and outer regional facilities having the highest scores (95.9 \pm 9.7 and 93.6 \pm 13.0 , respectively); and Leaving the $E D$-Delays (TA9) $(\mathrm{p}<0.01)$ with remote facilities having the highest scores $(81.3 \pm 39.1)$, indicating that patients at these facilities experienced fewer discharge-related delays.

When EDs were considered in terms of facility type, little variation in average topic area scores existed for 11 of the 13 topic areas (see Table 3). The two topic areas where a statistically significant difference was identified were: Environment and facilities (TA8) $(\mathrm{p}<0.01)$, with Group C and D acute facilities having the highest average scores $(93.9 \pm 21.6$ and 94.2 \pm 11.6 , respectively); and Leaving the ED - Delays (TA9) $(\mathrm{p}<0.01)$, with Group B and $\mathrm{C}$ acute facilities having the highest average scores $(72.1 \pm 44.9$ and $72.3 \pm 44.8$, respectively).

[Insert table 3 here]

\section{Discussion}


The aim of this study was to identify the extent to which ED patient-reported experiences scores differed depending on the location (level of remoteness) and types of facility providing emergency care. With the growing emphasis on consumer engagement in health services research and service co-design, patients are in a unique position to provide constructive information regarding the experiences of care they receive $\mathrm{e}^{23}$. Consequently, the results of the current study may have implications for researchers and service decisionmakers by guiding future research directions and service delivery models that aim to optimise patient experiences in the ED.

The results from this study indicate that smaller and more rurally located facilities performed better on many of the EDPES topic areas than larger, more metropolitan facilities. However, these differences were marginal, and statistical significance was detected for only two EDPES topics areas: Environment and facilities (TA8) and Leaving the ED - delays (TA9). Consequently, while we can suggest that smaller and more rurally located facilities provided better ED patient experiences, we are unable to determine the extent to which the differences identified between facility types and locations represent clinically meaningful differences i.e. whether these differences are real or noticed by patients in practice. This is an avenue for further research regarding the interpretation and usefulness of patient-reported experience data.

One group of Australian researchers have previously indicated that people living in rural areas are subjected to poorer experiences as a consequence of fewer resources, less experienced clinicians, lower equipment levels, reduced staff training, and poor care coordination in rural facilities ${ }^{24}$. However, this is discordant with the results of the present study, and 2017-18 Emergency Department Patient Survey data from the Bureau for Health Information (BHI) (New South Wales, Australia) ${ }^{25}$. The BHI data depicts a similar trend to the current study in that patients receiving care in smaller and more rurally located facilities 
were more likely to report "very good" overall patient experiences than patients receiving care in larger metropolitan facilities ${ }^{25}$. There may be a multitude of reasons that patients receiving care in smaller and more rural facilities report better experiences, such as having lower expectations for their care experience, exhibiting a lower socioeconomic status (e.g. of lower education and elderly) ${ }^{26}$, or less queuing and crowding in rural and remote EDs, which has previously shown to have a significant impact upon patient experience scores in the $\mathrm{USA}^{27}$. Future research should aim to distinguish between patient characteristics and facility characteristics of smaller and more rural EDs that are associated with better patient experiences. Practices and service models employed by smaller and more rural EDs may inform larger institutions, and promote the delivery of equivalent ED care experiences regardless of where a patient seeks care or their sociodemographic characteristics.

One of the poorest performing EDPES topic areas was Leaving the ED - coordination offollow-up services (TA12) (average score: 62.2 \pm 44.2 ). The item underpinning this topic area was: Were adequate arrangements made by the hospital for any services you needed? This result suggests that patients experienced inadequate referral to, or planning for, followup care upon leaving the ED. The link between ED presentations and discharge planning for subsequent follow-up by a healthcare provider in the community suggests that this mechanism is crucial to reducing return ED visits ${ }^{28}$. Previous Australian research has demonstrated the positive impacts of appropriate ED discharge planning, by reducing unnecessary patient re-presentation to the $\mathrm{ED}^{29}$. This, in-turn, has downstream clinical and financial impacts for both patients and hospitals. Consequently, future research and quality improvement initiatives should consider how to optimise ED coordination of follow-up services for patients being discharged into the community, and raise awareness as to its importance for patients' and hospitals' clinical and financial outcomes.

\section{Limitations}


Several limitations pertain to this study. First, patients diagnosed with a mental health problem were excluded from the sampling strategy employed in 2015, despite over 5\% of ED presentations during 2015-16 being coded as a mental and behavioural disorder principal diagnosis (ICD-10, Chapter V) ${ }^{30}$. The exclusion of these individuals may impact upon the generalisability of the results to this patient group. Second, participant recall bias may be possible as data collection was undertaken during the months of October - December, 2015, yet patient ED experiences occurred during the months of August - September, 2015.

There were also limitations with the survey itself. The validity and reliability of the EDPES is unknown. Further, several topic areas were comprised of an individual item whereas others contained up to 11 items. This meant that the average topic area scores were informed by varying amounts of information, and notably, the two lowest scoring topic areas were comprised of a single item. Moreover, due to the structure and logic of the survey as well as the scoring methodology, topic area scores were informed by a varying number of participants. For example, Leaving the ED - coordination of follow-up services (TA12) was not asked to $31.4 \%$ of survey participants and $68.9 \%$ of survey participants were excluded from the scoring as they 'did not need any services' (see Appendix 2). Additionally, our ability to undertake further analysis, to determine the dimensionality of the EDPES (using exploratory factor analysis), was prevented due to limitations associated with underlying survey logic.

A final limitation is that there were several sociodemographic and presentation-related differences between the sample and the population of patients who visited Queensland EDs during the same time period. Thus, while the sample was large at over 10,000 respondents, the responses may not reflect that of the population of patients visiting the ED during this period. 


\section{Conclusion}

This study aimed to identify the extent to which patient-reported experiences in QLD EDs differed depending on the location (level of remoteness) and types of facility providing care. The results of this study suggest that patients receiving ED care in smaller and more rurally located facilities reported significantly better experiences with respect to two of 13 topic areas than patients receiving care in larger, more metropolitan facilities. However, the magnitude of these differences were small. Future research should aim to determine what constitutes a clinically meaningful difference when comparing patient-reported experience data between groups. Further, to promote the delivery of equivalent ED care experiences irrespective of ED location or facility type, future research should aim to understand the characteristics of smaller and rurally located EDs that may facilitate better patient experiences.

\section{Acknowledgements}

This study was supported by an Emergency Medicine Foundation grant. CB is funded by an Australian Government Research Training Program (RTP) scholarship and a Griffith University Health Group top-up scholarship. We also thank the Health Innovation, Investment and Research Office of Queensland Health for supplying the data used in this study. No authors have competing interests to declare. 


\section{References}

1. Kmietowicz Z. A\&E attendances in England are growing twice as fast as population. BMJ. 2018;362.

2. Weiss AJ, Wier LM, Stocks C, Blanchard J. Overview of emergency department visits in the United States, 2011. Statistical brief \#174. Rockville (MD): Healthcare Cost and Utilization Project (HCUP); 2014 [cited 20 Sept 2019]. Available from: https://www.hcupus.ahrq.gov/reports/statbriefs/sb174-Emergency-Department-Visits-Overview.jsp.

3. Australian Institute of Health and Welfare. Emergency department care 2017-18: Australian hospital statistics. HSE 216. Canberra: AIHW; 2018 [Available from: https://www.aihw.gov.au/getmedia/9ca4c770-3c3b-42fe-b071-3d758711c23a/aihw-hse216.pdf.aspx?inline=true.

4. Australian Bureau of Statistics. Regional population growth, Australia, 2017-18. Cat. no. 3218.0. Canberra: ABS; 2019 [cited 15 May 2019]. Available from: https://www.abs.gov.au/ausstats/abs@.nsf/mf/3218.0.

5. Morley C, Unwin M, Peterson GM, Stankovich J, Kinsman L. Emergency department crowding: A systematic review of causes, consequences and solutions. PLoS One. 2018;13(8):e0203316.

6. Anhang Price R, Elliott MN, Zaslavsky AM, et al. Examining the role of patient experience surveys in measuring health care quality. Med Care Res Rev. 2014;71(5):522-54. 7. Institute for Healthcare Improvement. The IHI triple aim. USA: IHI; 2018 [cited 28 Nov 2018]. Available from:

http://www.ihi.org/Engage/Initiatives/TripleAim/Pages/default.aspx.

8. NHS Greater Preston CCG. Quality and clinical effectiveness. Preston: NHS Greater Preston CCG; 2018 [cited 8 May 2018]. Available from: 
9. Cosgrove DM, Fisher M, Gabow P, et al. Ten strategies to lower costs, improve quality, and engage patients: The view from leading health system CEOs. Health Aff. $2013 ; 32(2): 321-7$.

10. Sonis JD, Aaronson EL, Lee RY, Philpotts LL, White BA. Emergency department patient experience: A systematic review of the literature. J Patient Exp. 2018;5(2):101-6. 11. Gordon J, Sheppard LA, Anaf S. The patient experience in the emergency department: A systematic synthesis of qualitative research. Int Emerg Nurs. 2010;18(2):80-8. 12. Weinick RM, Becker K, Parast L, et al. Emergency department patient experience of care survey: Development and field test. Rand Health Q. 2014;30(4):5.

13. Nairn S, Whotton E, Marshal C, Roberts M, Swann G. The patient experience in emergency departments: A review of the literature. Accid Emerg Nurs. 2004;12(3):159-65. 14. Johnston EM, Johnston KJ, Bae J, et al. Impact of hospital characteristics on patients' experience of hospital care: Evidence from 14 states, 2009-2011. Patient Exp J. 2015;2(2):109-24.

15. Young GJ, Meterko M, Desai KR. Patient satisfaction with hospital care: Effects of demographic and institutional characteristics. Med Care. 2000;38(3):325-34.

16. Lehrman WG, Elliott MN, Goldstein E, Beckett MK, Klein DJ, Giordano LA. Characteristics of hospitals demonstrating superior performance in patient experience and clinical process measures of care. Med Care Res Rev. 2010;67(1):38-55.

17. Sjetne IS, Veenstra M, Stavem K. The effect of hospital size and teaching status on patient experiences with hospital care: A multilevel analysis. Med Care. 2007;45(3):252-8. 18. Chatterjee P, Joynt Maddox K. Patterns of performance and improvement in US Medicare's hospital star ratings, 2016-2017. BMJ Qual Saf. 2019;28(6):486-94.

19. Queensland Health. Queensland health: Emergency department patient experience survey 2015. Brisbane, QLD: Queensland Government Statistician's Office; 2015 [cited 12 
Feb 2018]. Available from:

https://www.health.qld.gov.au/_data/assets/pdf_file/0033/439809/edpes-2015.pdf.

20. National Health Service UK. Accident and emergency $(A \& E)$ department questionnaire. UK: NHS; 2009 [cited 20 Sept 2019]. Available from:

http://www.nhssurveys.org/Filestore/documents/AE_allquestions.pdf.

21. Australian Institute of Health and Welfare. Australian hospital peer groups. Health Services Series No. 66. Canberra: AIHW; 2015 [cited 15 May 2019]. 184]. Available from: https://www.aihw.gov.au/getmedia/79e7d756-7cfe-49bf-b8c00bbb0daa2430/14825.pdf.aspx?inline=true.

22. DoctorsConnect. Australian Standard Geographical Classification - Remoteness Area (ASGC-RA). Canberra: Australian Government Department of Health; 2006 [cited 2 March 2019]. Available from:

http://www.doctorconnect.gov.au/internet/otd/publishing.nsf/content/ra-intro.

23. Miller CL, Mott K, Cousins M, et al. Integrating consumer engagement in health and medical research: An Australian framework. Health Res Policy Syst. 2017;15(1):9.

24. Harrison R, Walton M, Mania E. Patient' experiences in Australian hospitals: An evidence check rapid review. Canberra: Sax Institute for the Australian Commission on Safety and

Quality in Health Care; 2015 [cited 2 March 2019]. Available from: https://www.safetyandquality.gov.au/sites/default/files/migrated/Patients-Experiences-inAustralian-Hospitals-rapid-review-of-the-evidence.pdf.

25. Bureau of Health Information. Emergency department patient survey. NSW, Australia: BHI; 2019 [cited 20 Sept 2019]. Available from:

http://www.bhi.nsw.gov.au/nsw patient_survey_program/emergency department_patient_su rvey. 
26. Garcia-Lacalle J, Martin E. Rural vs urban hospital performance in a 'competitive' public health service. Soc Sci Med. 2010;71(6):1131-40.

27. Pines JM, Iyer S, Disbot M, Hollander JE, Shofer FS, Datner EM. The effect of emergency department crowding on patient satisfaction for admitted patients. Acad Emerg Med. 2008;15(9):825-31.

28. Carmel AS, Steel P, Tanouye R, et al. Rapid primary care follow-up from the ED to reduce avoidable hospital admissions. West J Emerg Med. 2017;18(5):870-7.

29. Moss JE, Flower CL, Houghton LM, Moss DL, Nielsen DA, Taylor DM. A multidisciplinary care coordination team improves emergency department discharge planning practice. Med J Aust. 2002;177(8):435-9.

30. Australian Institute of Health and Welfare. Emergency department care 2015-16:

Australian hospital statistics. Health services series no. 72. Canberra: AIHW; 2016 [cited 15 May 2019]. Available from: https://www.aihw.gov.au/getmedia/ed894387-423b-42cd-8949- 
Table 1: Hospital peer groupings (derived from: Australian Institute of Health and Welfare Australian hospital peer groups 2015 report $^{21}$ )

\begin{tabular}{|c|c|c|c|c|}
\hline $\begin{array}{c}\text { Hospital } \\
\text { peer group }\end{array}$ & $\begin{array}{l}\text { Hospital sub- } \\
\text { group }\end{array}$ & Specific services available & Beds & Separations \\
\hline $\begin{array}{l}\text { Acute public } \\
\text { hospital }\end{array}$ & $\begin{array}{l}\text { Principal referral } \\
\text { hospitals }\end{array}$ & $\begin{array}{l}\text { - 24-hour emergency department } \\
\text { - ICU } \\
\text { - All or most of the following } \\
\text { specialised units: cardiac surgery, } \\
\text { neurosurgery, infectious diseases, } \\
\text { bone marrow transplant, organ } \\
\text { (liver, kidney, heart, lung or } \\
\text { pancreas) transplant, and burns } \\
\text { units }\end{array}$ & $\begin{array}{l}\text { Average: } \\
651 \\
\text { Range: } \\
358- \\
1,023\end{array}$ & $\begin{array}{l}\text { Average: } \\
67,649 \\
\text { Range: } \\
39,102- \\
98,831\end{array}$ \\
\hline $\begin{array}{l}\text { Acute public } \\
\text { hospital }\end{array}$ & $\begin{array}{l}\text { Public acute group } \\
\text { A hospitals }\end{array}$ & $\begin{array}{l}\text { - 24-hour emergency department } \\
\text { - ICU } \\
\text { - Coronary care unit } \\
\text { - Oncology unit }\end{array}$ & $\begin{array}{l}\text { Average: } \\
254 \\
\text { Range: } 79 \\
-503\end{array}$ & $\begin{array}{l}\text { Average: } \\
29,355 \\
\text { Range: } \\
7,736- \\
60,758\end{array}$ \\
\hline $\begin{array}{l}\text { Acute public } \\
\text { hospital }\end{array}$ & $\begin{array}{l}\text { Public acute group } \\
\text { B hospitals }\end{array}$ & $\begin{array}{l}\text { - 24-hour emergency department } \\
\text { - Elective surgeries } \\
\text { - Some combination of an } \\
\text { obstetrics unit, paediatric unit } \\
\text { and/or psychiatric unit }\end{array}$ & $\begin{array}{l}\text { Average: } \\
123 \\
\text { Range: } 66 \\
-373\end{array}$ & $\begin{array}{l}\text { Average: } \\
15,370 \\
\text { Range: } \\
4,977- \\
40,730 \\
\end{array}$ \\
\hline $\begin{array}{l}\text { Acute public } \\
\text { hospital }\end{array}$ & $\begin{array}{l}\text { Public acute group } \\
\text { C hospitals }\end{array}$ & $\begin{array}{l}\text { - Emergency department or } \\
\text { accident and emergency services } \\
\text { - Obstetric unit }\end{array}$ & $\begin{array}{l}\text { Average: } \\
42 \\
\text { Range: } 10 \\
-181 \\
\end{array}$ & $\begin{array}{l}\text { Average: } \\
3,453 \\
\text { Range: } 468 \\
-23,999 \\
\end{array}$ \\
\hline $\begin{array}{l}\text { Acute public } \\
\text { hospital }\end{array}$ & $\begin{array}{l}\text { Public acute group } \\
\text { D hospitals }\end{array}$ & nil & $\begin{array}{l}\text { Average: } \\
17 \\
\text { Range: } 0 \\
-75\end{array}$ & $\begin{array}{l}\text { Average: } \\
603 \\
\text { Range: } 200 \\
-2,787 \\
\end{array}$ \\
\hline $\begin{array}{l}\text { Very small } \\
\text { hospital }\end{array}$ & $\begin{array}{l}\text { Very small } \\
\text { hospital }\end{array}$ & nil (characterised by remoteness) & $\begin{array}{l}\text { Average: } \\
8 \\
\text { Range: } 0 \\
-34 \\
\end{array}$ & $\begin{array}{l}\text { Average: } 95 \\
\text { Range: } 0- \\
197\end{array}$ \\
\hline $\begin{array}{l}\text { Specialist } \\
\text { hospital }\end{array}$ & $\begin{array}{l}\text { Children's } \\
\text { hospitals }\end{array}$ & $\begin{array}{l}\text { - ICU } \\
\text { - Organ transplant unit } \\
\text { - Neurosurgery unit } \\
\text { - Comparable to Principal } \\
\text { referral hospitals } \\
\end{array}$ & $\begin{array}{l}\text { Average: } \\
216 \\
\text { Range: } \\
142-290\end{array}$ & $\begin{array}{l}\text { Average: } \\
24,603 \\
\text { Range: } \\
17,571- \\
34,589\end{array}$ \\
\hline $\begin{array}{l}\text { Specialist } \\
\text { hospital }\end{array}$ & $\begin{array}{l}\text { Women's } \\
\text { hospitals }\end{array}$ & $\begin{array}{l}\text { - ICU (including neonatal) } \\
\text { - Organ transplant unit } \\
\text { - Neurosurgery unit }\end{array}$ & $\begin{array}{l}\text { Average: } \\
168 \\
\text { Range: } \\
122-252\end{array}$ & $\begin{array}{l}\text { Average: } \\
15,369 \\
\text { Range: } \\
9,787- \\
25,502 \\
\end{array}$ \\
\hline $\begin{array}{l}\text { Specialist } \\
\text { hospital }\end{array}$ & $\begin{array}{l}\text { Women's and } \\
\text { children's } \\
\text { hospitals }\end{array}$ & As above & As above & As above \\
\hline
\end{tabular}

ICU $=$ intensive care unit. 
Table 2: Description of sociodemographic and presentation-related characteristics for the EDPES sample $(n=10,553)$ and concurrent QLD-wide population $(n=219,503)$ over the age of 16 years old

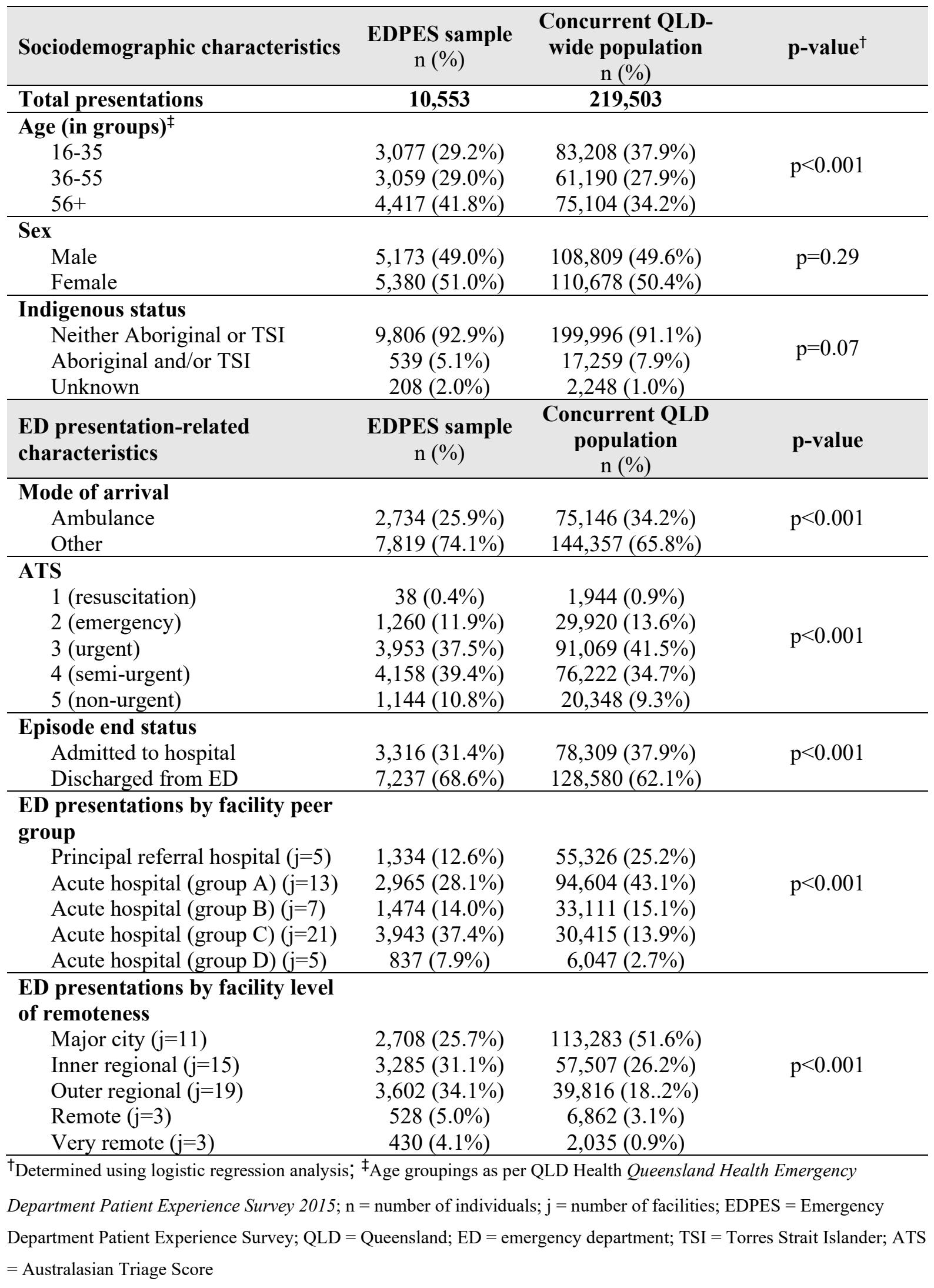


Table 3: Average EDPES topic area (TA) scores for participants across different facility types and location (level of remoteness)

\begin{tabular}{|c|c|c|c|c|c|c|c|c|c|c|c|c|c|}
\hline & TA1 & TA2 & TA3 & TA4 & TA5 & TA6 & TA7 & TA8 & TA9 & TA10 & TA11 & TA12 & TA14 \\
\hline & \multicolumn{13}{|c|}{ Mean \pm Standard deviation } \\
\hline $\begin{array}{l}\text { All participants } \\
(n=10,553)\end{array}$ & $\begin{array}{c}85.2 \\
\pm 23.0\end{array}$ & $\begin{array}{c}76.6 \\
\pm 27.5\end{array}$ & $\begin{array}{c}71.4 \\
\pm 31.3\end{array}$ & $\begin{array}{c}88.0 \\
\pm 18.8\end{array}$ & $\begin{array}{c}90.2 \\
\pm 15.2\end{array}$ & $\begin{array}{c}89.8 \\
\pm 23.6\end{array}$ & $\begin{array}{c}81.3 \\
\pm 33.5\end{array}$ & $\begin{array}{c}92.7 \\
\pm 13.7\end{array}$ & $\begin{array}{c}68.6 \\
\pm 46.4\end{array}$ & $\begin{array}{c}74.0 \\
\pm 28.9\end{array}$ & $\begin{array}{c}68.7 \\
\pm 32.4\end{array}$ & $\begin{array}{c}62.2 \\
\pm 44.2\end{array}$ & $\begin{array}{c}28.2 \\
\pm 45.0\end{array}$ \\
\hline Level of remoteness & \multicolumn{13}{|c|}{ Mean \pm Standard deviation } \\
\hline $\begin{array}{l}\text { Major city } \\
(\mathrm{j}=11)\end{array}$ & $\begin{array}{c}84.4 \\
\pm 23.3\end{array}$ & $\begin{array}{c}76.5 \\
\pm 27.4\end{array}$ & $\begin{array}{c}71.1 \\
\pm 31.6\end{array}$ & $\begin{array}{c}88.1 \\
\pm 18.6\end{array}$ & $\begin{array}{c}90.0 \\
\pm 15.3\end{array}$ & $\begin{array}{c}89.7 \\
\pm 23.2\end{array}$ & $\begin{array}{c}81.3 \\
\pm 33.3\end{array}$ & $\begin{array}{c}91.4 \\
\pm 14.7\end{array}$ & $\begin{array}{c}63.9 \\
\pm 48.0\end{array}$ & $\begin{array}{c}74.4 \\
\pm 27.8\end{array}$ & $\begin{array}{c}69.1 \\
\pm 32.0\end{array}$ & $\begin{array}{c}63.0 \\
\pm 43.9\end{array}$ & $\begin{array}{c}26.9 \\
\pm 44.4\end{array}$ \\
\hline $\begin{array}{l}\text { Inner regional } \\
(\mathrm{j}=15)\end{array}$ & $\begin{array}{c}85.5 \\
\pm 23.0\end{array}$ & $\begin{array}{c}76.7 \\
\pm 27.5\end{array}$ & $\begin{array}{c}71.5 \\
\pm 31.3\end{array}$ & $\begin{array}{c}87.9 \\
\pm 19.1\end{array}$ & $\begin{array}{c}89.9 \\
\pm 15.5\end{array}$ & $\begin{array}{c}89.6 \\
\pm 23.6\end{array}$ & $\begin{array}{c}81.1 \\
\pm 33.7\end{array}$ & $\begin{array}{c}92.3 \\
\pm 13.8\end{array}$ & $\begin{array}{c}69.4 \\
\pm 46.1\end{array}$ & $\begin{array}{c}73.1 \\
\pm 29.7\end{array}$ & $\begin{array}{c}68.9 \\
\pm 32.8\end{array}$ & $\begin{array}{c}63.2 \\
\pm 44.2\end{array}$ & $\begin{array}{c}28.8 \\
\pm 45.3\end{array}$ \\
\hline $\begin{array}{l}\text { Outer regional } \\
(j=19)\end{array}$ & $\begin{array}{c}85.3 \\
\pm 22.8\end{array}$ & $\begin{array}{c}76.6 \\
\pm 27.6\end{array}$ & $\begin{array}{c}71.5 \\
\pm 31.0\end{array}$ & $\begin{array}{c}88.1 \\
\pm 18.8\end{array}$ & $\begin{array}{c}90.2 \\
\pm 15.3\end{array}$ & $\begin{array}{c}90.0 \\
\pm 23.7\end{array}$ & $\begin{array}{r}81.8 \\
\pm 33.2\end{array}$ & $\begin{array}{c}93.6 \\
\pm 13.0\end{array}$ & $\begin{array}{c}69.0 \\
\pm 46.3\end{array}$ & $\begin{array}{c}74.3 \\
\pm 28.6\end{array}$ & $\begin{array}{c}67.7 \\
\pm 32.4\end{array}$ & $\begin{array}{c}62.1 \\
\pm 44.4\end{array}$ & $\begin{array}{l}28.5 \\
\pm 45.1\end{array}$ \\
\hline $\begin{array}{l}\text { Remote } \\
(j=3)\end{array}$ & $\begin{array}{c}84.6 \\
\pm 22.6\end{array}$ & $\begin{array}{c}77.1 \\
\pm 26.1\end{array}$ & $\begin{array}{c}71.0 \\
\pm 31.5\end{array}$ & $\begin{array}{c}87.5 \\
\pm 19.2\end{array}$ & $\begin{array}{r}91.0 \\
\pm 13.1\end{array}$ & $\begin{array}{c}90.1 \\
\pm 21.9\end{array}$ & $\begin{array}{c}81.0 \\
\pm 34.4\end{array}$ & $\begin{array}{c}92.6 \\
\pm 14.3\end{array}$ & $\begin{array}{c}81.3 \\
\pm 39.1\end{array}$ & $\begin{array}{c}76.7 \\
\pm 29.6\end{array}$ & $\begin{array}{c}70.3 \\
\pm 31.6\end{array}$ & $\begin{array}{c}57.5 \\
\pm 44.4\end{array}$ & $\begin{array}{c}29.1 \\
\pm 45.5\end{array}$ \\
\hline $\begin{array}{l}\text { Very remote } \\
(j=3)\end{array}$ & $\begin{array}{c}86.3 \\
\pm 22.1\end{array}$ & $\begin{array}{c}76.7 \\
\pm 27.7\end{array}$ & $\begin{array}{c}72.5 \\
\pm 31.5\end{array}$ & $\begin{array}{c}89.1 \\
\pm 17.1\end{array}$ & $\begin{array}{c}91.6 \\
\pm 12.7\end{array}$ & $\begin{array}{c}88.8 \\
\pm 26.8\end{array}$ & $\begin{array}{c}79.1 \\
\pm 33.7\end{array}$ & $\begin{array}{l}95.9 \\
\pm 9.7\end{array}$ & $\begin{array}{c}72.6 \\
\pm 44.7\end{array}$ & $\begin{array}{c}72.5 \\
\pm 30.4\end{array}$ & $\begin{array}{c}70.0 \\
\pm 32.0\end{array}$ & $\begin{array}{c}56.7 \\
\pm 45.0\end{array}$ & $\begin{array}{c}27.7 \\
\pm 44.8\end{array}$ \\
\hline p-value ${ }^{\dagger}$ & 0.61 & 0.99 & 0.93 & 0.74 & 0.14 & 0.95 & 0.82 & $<0.01$ & $<0.01$ & 0.83 & 0.38 & 0.56 & 0.62 \\
\hline Facility type & \multicolumn{13}{|c|}{ Mean \pm Standard deviation } \\
\hline $\begin{array}{l}\text { Principal } \\
\text { referral }(\mathrm{j}=5)\end{array}$ & $\begin{array}{c}84.5 \\
\pm 23.9\end{array}$ & $\begin{array}{c}76.4 \\
\pm 27.4\end{array}$ & $\begin{array}{c}72.5 \\
\pm 31.3\end{array}$ & $\begin{array}{c}88.9 \\
\pm 17.5\end{array}$ & $\begin{array}{c}90.0 \\
\pm 14.8\end{array}$ & $\begin{array}{c}89.9 \\
\pm 23.7\end{array}$ & $\begin{array}{c}82.6 \\
\pm 32.4\end{array}$ & $\begin{array}{c}91.2 \\
\pm 15.1\end{array}$ & $\begin{array}{c}61.2 \\
\pm 48.8\end{array}$ & $\begin{array}{c}74.2 \\
\pm 27.3\end{array}$ & $\begin{array}{c}69.6 \\
\pm 31.8\end{array}$ & $\begin{array}{c}65.1 \\
\pm 44.2\end{array}$ & $\begin{array}{c}27.6 \\
\pm 44.7\end{array}$ \\
\hline $\begin{array}{l}\text { Acute - Group A } \\
(\mathrm{j}=13)\end{array}$ & $\begin{array}{c}85.7 \\
\pm 22.3\end{array}$ & $\begin{array}{c}76.4 \\
\pm 27.7\end{array}$ & $\begin{array}{c}70.2 \\
\pm 31.7\end{array}$ & $\begin{array}{c}87.7 \\
\pm 18.8\end{array}$ & $\begin{array}{c}89.7 \\
\pm 15.8\end{array}$ & $\begin{array}{c}90.6 \\
\pm 22.1\end{array}$ & $\begin{array}{c}80.7 \\
\pm 34.1\end{array}$ & $\begin{array}{c}91.7 \\
\pm 14.6\end{array}$ & $\begin{array}{c}64.9 \\
\pm 47.7\end{array}$ & $\begin{array}{c}74.4 \\
\pm 28.2\end{array}$ & $\begin{array}{c}68.8 \\
\pm 32.6\end{array}$ & $\begin{array}{c}65.7 \\
\pm 42.5\end{array}$ & $\begin{array}{c}27.5 \\
\pm 44.7\end{array}$ \\
\hline $\begin{array}{l}\text { Acute - Group B } \\
(\mathrm{j}=7)\end{array}$ & $\begin{array}{c}84.7 \\
\pm 24.0\end{array}$ & $\begin{array}{c}76.7 \\
\pm 27.5\end{array}$ & $\begin{array}{c}71.1 \\
\pm 31.6\end{array}$ & $\begin{array}{c}87.5 \\
\pm 19.2\end{array}$ & $\begin{array}{c}89.9 \\
\pm 15.4\end{array}$ & $\begin{array}{c}89.3 \\
\pm 23.1\end{array}$ & $\begin{array}{c}80.7 \\
\pm 33.9\end{array}$ & $\begin{array}{c}91.8 \\
\pm 14.2\end{array}$ & $\begin{array}{c}72.1 \\
\pm 44.9\end{array}$ & $\begin{array}{c}71.4 \\
\pm 31.7\end{array}$ & $\begin{array}{c}68.9 \\
\pm 31.7\end{array}$ & $\begin{array}{c}61.1 \\
\pm 45.1\end{array}$ & $\begin{array}{l}28.3 \\
\pm 45.1\end{array}$ \\
\hline $\begin{array}{l}\text { Acute - Group C } \\
(\mathrm{j}=\mathbf{2 1})\end{array}$ & $\begin{array}{c}85.6 \\
\pm 22.6\end{array}$ & $\begin{array}{c}76.7 \\
\pm 27.3\end{array}$ & $\begin{array}{c}71.9 \\
\pm 31.0\end{array}$ & $\begin{array}{c}88.2 \\
\pm 18.8\end{array}$ & $\begin{array}{c}90.6 \\
\pm 14.9\end{array}$ & $\begin{array}{c}89.5 \\
\pm 24.4\end{array}$ & $\begin{array}{c}81.3 \\
\pm 33.4\end{array}$ & $\begin{array}{c}93.9 \\
\pm 12.6\end{array}$ & $\begin{array}{c}72.3 \\
\pm 44.8\end{array}$ & $\begin{array}{c}74.3 \\
\pm 28.7\end{array}$ & $\begin{array}{c}68.0 \\
\pm 32.7\end{array}$ & $\begin{array}{c}60.0 \\
\pm 45.0\end{array}$ & $\begin{array}{c}28.7 \\
\pm 45.3\end{array}$ \\
\hline $\begin{array}{l}\text { Acute - Group D } \\
(\mathrm{j}=5)\end{array}$ & $\begin{array}{c}84.3 \\
\pm 23.8\end{array}$ & $\begin{array}{c}77.0 \\
\pm 27.5\end{array}$ & $\begin{array}{c}72.2 \\
\pm 30.8\end{array}$ & $\begin{array}{c}87.9 \\
\pm 19.8\end{array}$ & $\begin{array}{c}90.5 \\
\pm 14.5\end{array}$ & $\begin{array}{c}88.6 \\
\pm 25.1\end{array}$ & $\begin{array}{c}82.0 \\
\pm 32.9\end{array}$ & $\begin{array}{c}94.2 \\
\pm 11.6\end{array}$ & $\begin{array}{c}69.9 \\
\pm 45.9\end{array}$ & $\begin{array}{c}75.4 \\
\pm 29.0\end{array}$ & $\begin{array}{c}69.3 \\
\pm 32.2\end{array}$ & $\begin{array}{c}59.2 \\
\pm 44.4\end{array}$ & $\begin{array}{c}28.5 \\
\pm 45.2\end{array}$ \\
\hline p-value ${ }^{\dagger}$ & 0.23 & 0.97 & 0.09 & 0.25 & 0.16 & 0.43 & 0.71 & $<0.01$ & $<0.01$ & 0.70 & 0.67 & 0.10 & 0.87 \\
\hline
\end{tabular}

TA5 $=$ Care and treatment; TA6 $=$ Tests; TA7 = Pain; TA8 = Environment and facilities; TA9 = Leaving the ED - Delays; TA10 = Leaving the ED - Medications; TA11 = Leaving the ED -

Information; TA12 = Leaving the ED - Coordination of follow-up services; TA14 = Complaints. 
Figure 1: EDPES topic areas based on ${ }^{19}$ (*identifies items only asked of discharged patients)

Figure legend: Flow diagram depicting the EDPES topics areas as defined by QH, evidencing the flow of the survey in correlation to the patient journey through the ED. 